\title{
Genetic structure of Balearic honeybee populations based on microsatellite polymorphism
}

\author{
Pilar De la Rúa ${ }^{a *}$, José GALIÁN ${ }^{\mathrm{a}}$, \\ José Serrano $^{\mathrm{a}}$, Robin F.A. Moritz ${ }^{\mathrm{b}}$ \\ a Departamento de Biología Animal, Facultad de Veterinaria, Apdo. 4021, \\ Universidad de Murcia, 30071 Murcia, Spain \\ ${ }^{\mathrm{b}}$ Institute of Zoology, Martin-Luther-University Halle-Wittenberg, \\ Kröllwitzer Str. 44, 06099 Halle/Saale, Germany
}

(Received 2 January 2002; accepted 21 November 2002)

\begin{abstract}
The genetic variation of honeybee colonies collected in 22 localities on the Balearic Islands (Spain) was analysed using eight polymorphic microsatellite loci. Previous studies have demonstrated that these colonies belong either to the African or west European evolutionary lineages. These populations display low variability estimated from both the number of alleles and heterozygosity values, as expected for the honeybee island populations. Although genetic differentiation within the islands is low, significant heterozygote deficiency is present, indicating a subpopulation genetic structure. According to the genetic differentiation test, the honeybee populations of the Balearic Islands cluster into two groups: Gimnesias (Mallorca and Menorca) and Pitiusas (Ibiza and Formentera), which agrees with the biogeography postulated for this archipelago. The phylogenetic analysis suggests an Iberian origin of the Balearic honeybees, thus confirming the postulated evolutionary scenario for Apis mellifera in the Mediterranean basin. The microsatellite data from Formentera, Ibiza and Menorca show that ancestral populations are threatened by queen importations, indicating that adequate conservation measures should be developed for protecting Balearic bees.
\end{abstract}

honeybee / microsatellites / population structure / genetic diversity / Balearic Islands

\section{INTRODUCTION}

The honeybee Apis mellifera $\mathrm{L}$. has been the object of numerous studies from different points of view. Ruttner [32] morphologically characterised 24 subspecies, and grouped them into four branches according to their geographical distribution. The Mediterranean branch shows a complex pattern of mitochondrial DNA haplotypes $[14,18,21]$ and microsatellite loci $[11,16,22]$, since the

\footnotetext{
* Correspondence and reprints
}

E-mail: pdelarua@um.es 
west Mediterranean/north European lineage has two haplotypes with numerous variants ( $\mathrm{M}$ and $\mathrm{A}$ ), whereas that from the central Mediterranean/southeast Europe shows the $\mathrm{C}$ haplotype except for A. mellifera sicula, which bears $\mathrm{A}$ haplotypes. The latest scenario proposed for A. mellifera evolutionary lineages defined by molecular approaches, considers two more lineages, one called $\mathrm{O}$ which includes the Near and Middle Eastern subspecies and another lineage called Y including the A. m. yemenitica subspecies from Ethiopia [16].

The Iberian honeybee, Apis mellifera iberica, has been extensively analysed through morphometrical $[4,25,27,32]$ and molecular studies (enzyme electrophoresis [3,38], mtDNA variation [5, 14, 18-21,34,37], and microsatellites [9, $11,14,22])$. Morphometrical and mitochondrial data indicate the hybrid status of this subspecies between the African A. m. intermissa and the west European A. $m$. mellifera, since the African (A) haplotypes decreased gradually from the South to North while the European (M) haplotypes increased. On the contrary, Franck et al. [14] found that Spanish and Portuguese honeybee populations are very similar to the French populations when considering microsatellite markers, although recent analyses of different Iberian populations do not completely support these findings [9].

It is expected that honeybee populations from the Balearic Islands are related to those of the Iberian Peninsula, according to the faunistic connections already known between both areas [2]. However, recent analyses have shown that African haplotypes predominate in honeybees from the Balearic archipelago [7], as reported for southern Iberia and other Mediterranean islands (Greek Islands: [19]; Malta: [35]; Sicily: [15,36]).

The purpose of this study was to determine the genetic structure of Balearic honeybee populations through the analysis of microsatellites, and to assess their evolutionary relationships to Iberian and African populations. Microsatellites are nuclear DNA markers that show a remarkable polymorphism in the number of alleles per locus and have been extensively used in population genetic studies. In Apis mellifera they have also been applied in investigations on lineage evolution [11], theoretical models of mutations [11,12] and reproductive behaviour and socio-biology (reviewed in [39]).

\section{MATERIALS AND METHODS}

\subsection{Sampling}

A total of 98 colonies were sampled from 22 different localities distributed on Mallorca, Menorca, Ibiza and Formentera during August 1999 and February 2000 (Fig. 1). The hives were opened and the bees were trapped from the inner frames to prevent the collection of drifting bees. The bees were immediately killed by immersion in absolute ethanol and kept at $-20^{\circ} \mathrm{C}$ until laboratory 


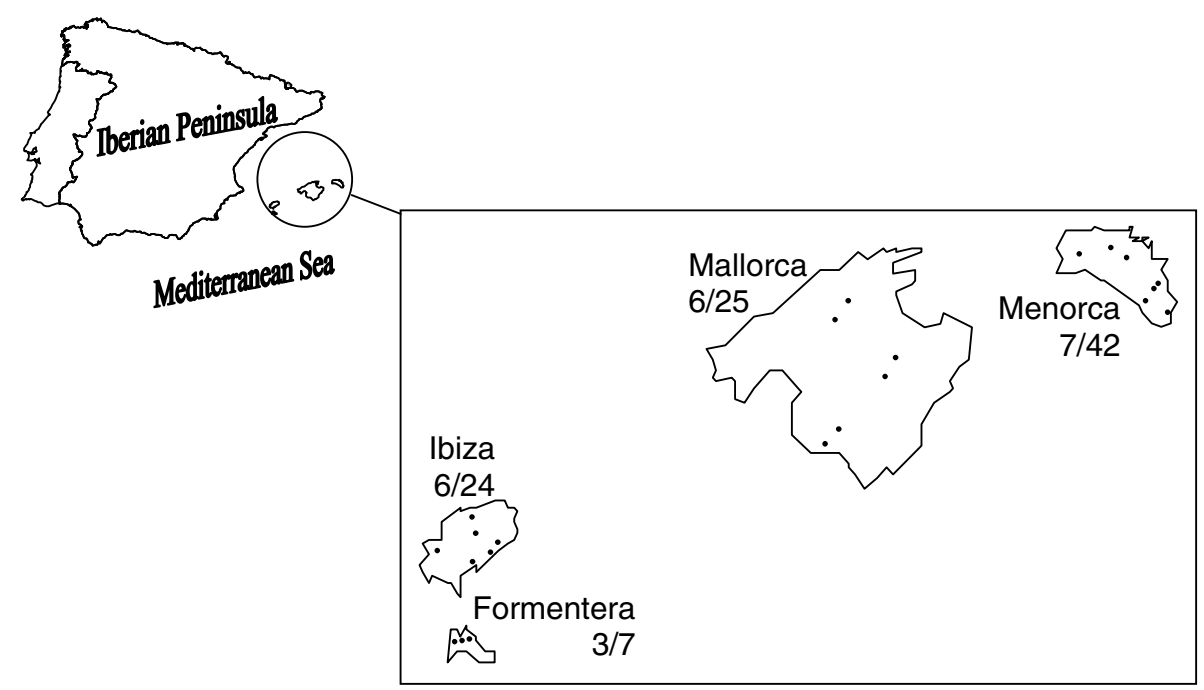

Figure 1. Sampling location of Apis mellifera from the Balearic Islands for the microsatellite analysis. Number of sampled localities (left) and colonies (right) are indicated below the island name.

processing. All these colonies have been previously characterised by analysing the mtDNA variation [7] and some of them by morphometric analysis [29].

\subsection{Molecular analysis}

Total DNA was extracted from one worker thorax per colony $(\mathrm{N}=98)$ after rinsing the bees in insect buffer for one hour according to Garnery et al. [19]. DNA isolation was performed following the Chelex method [40] with slight modifications. The same samples were used for both mtDNA and microsatellite analyses.

Eight polymorphic microsatellite loci were analysed: $B 124, A 113, A 7$, $A 35, A 24, A 28$ and $A 88[10,11]$ and $A 8$ [14]. Multiplex PCR reactions were performed when the annealing temperature and the $\mathrm{MgCl}_{2}$ concentration coincided. The reactions were done with fluorescent labelled primers and separated on a DNA automated sequencer (ABI 310, Applied Biosystems).

\subsection{Statistical analyses}

Microsatellite allele sizes were scored by comparing the length of the PCR fragments to the standard 100 bp TAMRA (Perkin-Elmer). Population parameters and estimates of gene diversity [26] were calculated with the POPGENE package (vers. 1.31). The exact test for Hardy-Weinberg equilibrium, genotypic linkage disequilibrium and genetic structure (genotypic differentiation) were 
computed with GENEPOP version 1.2 (http://wbiomed.curtin.edu.au/genepop; [30]). Microsatellite variation within and between populations was analysed with FSTAT [23]. The significance value for multiple comparisons was calculated using the sequential Bonferroni procedure [31].

\subsection{Phylogenetic analysis}

The results of seven microsatellite loci $(B 124, A 113, A 7, A 24, A 28, A 8$ and $A 88$ ) in the Balearic populations were combined with the data from other geographically close populations (Castilla, Andalucia and Portugal in the Iberian Peninsula and southern and northern Rif and southern Morocco in North Africa; data from Franck et al. [14]) to analyse their phylogenetic relationships. The neighbour-joining method [33] and the chord distance of Cavalli-Sforza and Edwards [1] were used to obtain an unrooted tree with bootstrap values over 2000 iterations of the data set [24]. Programmes included in the PHYLIP package (version 3.5c; [13]) were used for this purpose.

\section{RESULTS}

\subsection{Genetic diversity}

The number of alleles detected and the observed and expected heterozygosities $(\mathrm{Ho}$ and $\mathrm{He}$ ) per microsatellite locus are shown in Table I (detailed data for allele frequencies at each locus are available upon request). The overall population parameters per island are shown in Table II. The gene diversity varied between $0.589 \pm 0.247$ (Mallorca) and $0.349 \pm 0.331$ (Formentera).

The Fisher method was used to test whether the honeybees sampled in one island could be considered as a single population. Genotypic differentiation within the islands was not significant $(P>0.706)$ whereas it was significant when the four islands were compared $(P<0.05)$.

Seven significant departures of the Hardy-Weinberg equilibrium were detected among $32(8 \times 4)$ locus per population combinations, when only two were expected by chance at the $5 \%$ level. Five tests were significant in Menorca, one in Ibiza and one in Mallorca. The Fis estimates as a measure of heterozygote deficiency or excess, gave values ranging between 0.329 (Menorca) and 0.149 (Formentera), thus indicating a heterozygote deficiency in all the islands.

Exact tests for linkage disequilibrium resulted in one significant value out of 82 pairwise comparisons, which is expected to occur by chance at the $5 \%$ level.

\subsection{Population relationships}

The Fisher exact test for multilocus genic and genetic differentiation indicated that each island population was significantly differentiated from the others. 
Table I. Number of alleles detected, and observed and expected heterozygosities (Ho and $\mathrm{He}$ ) per microsatellite locus in Apis mellifera populations from the Balearic Islands. The sample size from each island and locus is indicated in brackets.

\begin{tabular}{|c|c|c|c|c|}
\hline Locus/alleles & Mallorca & Menorca & Ibiza & Formentera \\
\hline$B 124$ & (28) & (42) & (24) & (7) \\
\hline alleles & 12 & 15 & 9 & 4 \\
\hline $\mathrm{Ho}$ & 0.643 & 0.667 & 0.458 & 0.286 \\
\hline $\mathrm{He}$ & 0.862 & 0.866 & 0.770 & 0.643 \\
\hline A113 & (21) & (42) & (23) & (6) \\
\hline alleles & 14 & 6 & 8 & 7 \\
\hline Ho & 0.857 & 0.714 & 0.696 & 1.000 \\
\hline $\mathrm{He}$ & 0.853 & 0.743 & 0.798 & 0.792 \\
\hline$A 24$ & (19) & (40) & (23) & (6) \\
\hline alleles & 3 & 6 & 3 & 3 \\
\hline Ho & 0.105 & 0.100 & 0.217 & 0.500 \\
\hline $\mathrm{He}$ & 0.101 & 0.311 & 0.199 & 0.403 \\
\hline$A 28$ & $(25)$ & (43) & (24) & (7) \\
\hline alleles & 5 & 3 & 1 & 1 \\
\hline Ho & 0.600 & 0.372 & 0.000 & 0.000 \\
\hline $\mathrm{He}$ & 0.678 & 0.414 & 0.000 & 0.000 \\
\hline A35 & (24) & (42) & (23) & (6) \\
\hline alleles & 5 & 5 & 8 & 5 \\
\hline Ho & 0.625 & 0.548 & 0.696 & 0.833 \\
\hline $\mathrm{He}$ & 0.707 & 0.581 & 0.764 & 0.681 \\
\hline$A 7$ & (20) & (21) & (17) & (4) \\
\hline alleles & 5 & 6 & 3 & 1 \\
\hline Ho & 0.400 & 0.191 & 0.059 & 0.000 \\
\hline $\mathrm{He}$ & 0.529 & 0.601 & 0.164 & 0.000 \\
\hline$A 8$ & (30) & (37) & (23) & (5) \\
\hline alleles & 7 & 8 & 4 & 1 \\
\hline Ho & 0.200 & 0.405 & 0.652 & 0.000 \\
\hline $\mathrm{He}$ & 0.519 & 0.763 & 0.717 & 0.000 \\
\hline A88 & (19) & (37) & (23) & (6) \\
\hline alleles & 5 & 7 & 2 & 2 \\
\hline Ho & 0.368 & 0.216 & 0.044 & 0.000 \\
\hline $\mathrm{He}$ & 0.468 & 0.415 & 0.043 & 0.278 \\
\hline
\end{tabular}

Multilocus Fst values (Tab. III) varied between 0.049 (Mallorca and Menorca) and 0.276 (Mallorca and Formentera), the highest values being between Mallorca and Formentera (0.276) and between Mallorca and Ibiza (0.219). The lowest multilocus $F s t$ values are in agreement with the geographical grouping 
Table II. Multilocus microsatellite variation in the Balearic honeybee populations. $N$ is the mean sample size, $n$ is the mean and standard error of the observed number of alleles, $\mathrm{Ho}$ and $\mathrm{He}$ are the observed and the expected heterozygosity respectively. The Fis values are also shown.

\begin{tabular}{lrcccc}
\hline Population & $N$ & $n$ & Ho & He & Fis \\
\hline Mallorca & 30 & $7.00 \pm 3.89$ & $0.475 \pm 0.251$ & $0.589 \pm 0.247$ & 0.217 \\
Menorca & 43 & $7.00 \pm 3.55$ & $0.402 \pm 0.226$ & $0.587 \pm 0.196$ & 0.329 \\
Ibiza & 24 & $4.75 \pm 3.11$ & $0.353 \pm 0.307$ & $0.432 \pm 0.359$ & 0.205 \\
Formentera & 7 & $3.00 \pm 2.20$ & $0.327 \pm 0.408$ & $0.349 \pm 0.331$ & 0.149 \\
\hline
\end{tabular}

Table III. Pairwise Fst values between pairs of honeybee populations from the Balearic Islands $\left({ }^{*} P>0.05\right)$.

\begin{tabular}{lccc}
\hline & Mallorca & Menorca & Ibiza \\
\hline Mallorca & & & \\
Menorca & 0.049 & & \\
Ibiza & 0.219 & 0.149 & \\
Formentera & 0.276 & 0.197 & $0.065^{*}$ \\
\hline
\end{tabular}

of the islands: Gimnesias (Mallorca and Menorca) and Pitiusas (Ibiza and Formentera).

\subsection{Phylogenetic analysis}

In the unrooted neighbour-joining tree (Fig. 2) there were two well-separated groups, the Iberian populations together with the Balearic Islands and the African populations. Within the Balearic populations, Mallorca and Menorca formed a cluster whereas Ibiza branched together with Formentera, confirming the result provided by the analysis of the genetic distance.

\section{DISCUSSION}

\subsection{Honeybee population structure in the Balearic Islands}

The comparison of the genetic variability between the Balearic populations and other continental (Spanish and African, data from Franck et al. $[14,17]$ and De la Rúa et al. [9]) or island populations (data from De la Rúa et al. [6]), shows that the heterozygosity values and the microsatellite allele number are similar to those in the Iberian and the Canarian populations, and thus lower than those from northern Morocco. The lowest values were observed in Formentera, the smallest island with the smallest population (there are only four apiaries). 


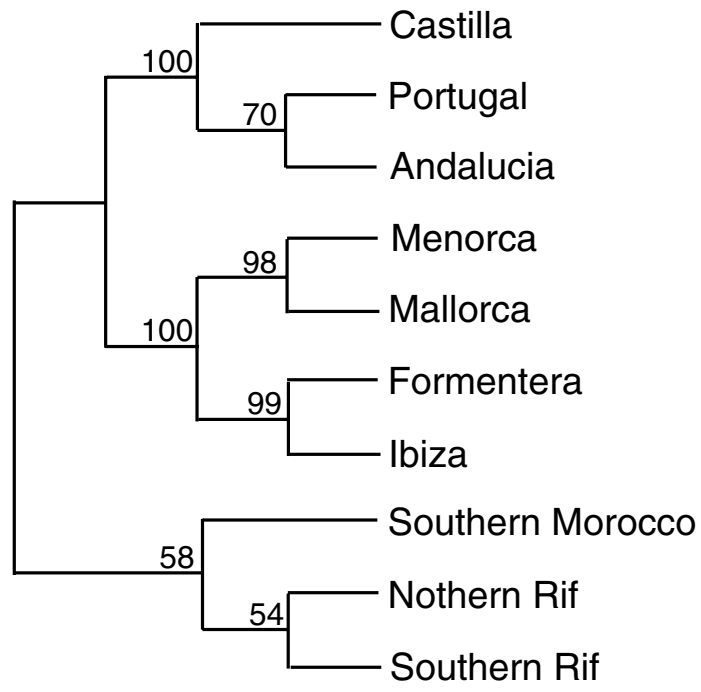

Figure 2. Phylogenetic relationships (unrooted tree) of the Balearic, Iberian, and African honeybee populations based on the neighbour-joining method and CavalliSforza and Edwards chord distance obtained from the microsatellite data. Bootstrap values are noted as percentages and were computed over 2000 replicates of the data set.

The low degree of heterozygosity in Formentera is indicative of a recent bottleneck caused by massive losses of colonies in the early nineties due to a Varroa infection and followed by the recovery of the population from a few colonies imported from Ibiza and the mainland, according to the information given by the local beekeepers. The mitochondrial variation detected in the island is also very low (De la Rúa et al. [7]).

The test for population differentiation indicates that there are not significant genotypic differences within each island. However, Fis values were high in every island population (Tab. III) suggesting that honeybee colonies have been divided into subpopulations or demes within the islands, leading to a deficit in heterozygotes in the pooled population due to the Wahlund effect. The existence of subpopulations within the islands may be the result of at least two factors, the existence of more than one mating area in the islands and the propagation of selected colonies by the beekeepers through repeated and controlled swarming. These factors would contribute to (i) the observed genotypic homogenisation throughout a given island, and (ii) at the same time a heterozygote deficiency.

Such a genetic structure was not expected in Mallorca, which in spite of being the largest island is very homogeneous for the African mitochondrial A2 haplotype (100\%). As noted by De la Rúa et al. [7], this finding suggests that 
honeybee populations from Mallorca descend from a "natural" colonisation, that is, are derived from ancestors that colonised the Mediterranean islands and Europe after the last glaciation period $[33,36]$ and have not undergone further introgression events.

On the contrary, the microsatellite genetic homogeneity within Menorca and Ibiza, contrasts with the presence of mtDNA haplotypes from two evolutionary lineages A and M [7]. This result is indicative of recent introgression events, apparently caused by the local beekeepers. As stated in a former paper dealing with the mitochondrial haplotype variation [7], this molecular marker indicates the introduction of the west European A. mellifera mellifera (with the M haplotype) in Menorca - perhaps during the XVIII and XIX centuries when French and British settlements were present on the island - and in Ibiza. Local beekeepers from Ibiza have confirmed the importation of colonies from Iberia during the last decades, especially from Valencia in eastern Spain where the proportion of $\mathrm{M}$ haplotypes is about 50\% (De la Rúa et al., unpubl. data). A similar situation has been found in the honeybee population of Tenerife $[6,8]$, where recent importations of south-eastern Mediterranean races with the $\mathrm{C}$ haplotype have occurred.

\subsection{Evolutionary history of the Balearic honeybees}

The results of the pairwise Fst significance test based on microsatellite allele frequencies, indicate that the Balearic archipelago can be divided into two groups, one including Mallorca and Menorca (the Gimnesias islands) and the other Ibiza and Formentera (the Pitiusas islands). This clustering is in agreement with the known biogeography of the archipelago [2] and the grouping obtained with mitochondrial [7] and morphological [29] data, and reflects the separate history of both island groups. Mallorca and Menorca became separated from the Iberian Peninsula before Ibiza and Formentera, and underwent several episodes of geographical separation and subsequent connection during recent geological times. This grouping is also mirrored in the N-J population tree, since the two clades made up by the Balearic populations are supported by high bootstrap values. All other animal groups of the Balearic Islands (except birds) show the same pattern of geographic affinity depicted by honeybee populations [28].

The microsatellite data of Balearic honeybees suggest that a population bottleneck occurred when the islands were colonised by ancestors coming from Iberia or North Africa, thus giving rise to the observed reduction in the number and the levels of heterozygosity of microsatellite alleles. This hypothesis has also been invoked for explaining a similar reduction in microsatellite variability in western European populations (from Iberia to France) in comparison to African ones [15]. Such a reduction was observed in honeybee populations from southeast Spain as well [10]. In the Canary Islands [6] 
there is also low microsatellite variability in spite of their geographic relatedness to the African mainland, perhaps due to a founder effect during island colonisation.

The clade formed by the Iberian and the Balearic populations support the close biogeographic relatedness of the islands to the Iberian Peninsula [2], which indicates a peninsular origin of the Balearic honeybee populations. The presence of African haplotypes in other Mediterranean islands [15, 19,35,36], as well as in Iberian and Balearic honeybee populations suggests colonisation events in the southern Mediterranean basin by African stocks. Ruttner [32] and Sheppard et al. [35] have postulated that the distribution of honeybee populations of African origin (A. m. iberica, A. m. sicula and A. m. ruttneri) in the Mediterranean islands is a consequence of successive colonisation events during the Pleistocene glaciations.

\subsection{Conservation of Balearic honeybees}

The conclusions derived from microsatellite and mitochondrial data indicate that Balearic honeybee populations still have a natural genome worth of being protected for conservation and applied purposes. In particular, Mallorca seems to harbour the best preserved population. On the contrary, the case of Formentera clearly shows the threats to the local Balearic populations due to a combination of the effect of diseases and low population size. Most local bees likely disappeared from Formentera and have been replaced by imported colonies from Ibiza or Valencia (East Spain). Ibiza and - to a lesser extent - Menorca, show clues of recent introgression events that have substantially changed the genetic pool of the ancestral local populations. Therefore, beekeepers and the Balearic Government must be aware of the effects of queen importations if protection policies are to be developed.

\section{ACKNOWLEDGEMENTS}

Special thanks are given to José A. Acosta for his help and advice during the sampling travel to Mallorca and Menorca. We are indebted to the beekeepers Jaume Martorell, Joan Massanet, Tomeu Gual, Gabriel Vicens, Baltasar Pons and Antonio Cerdá from Mallorca, Sebastiá Pons, José Llufriú, Antoni Truyol and Miquel Truyol from Menorca, Francisco Clapés and José Suñer from Ibiza and Vicente Ribas and Pascual Mayans from Formentera, for providing samples. This study has been supported by the DAAD-Acciones Integradas Hispano-Alemanas HA 1998-0043, and the projects RZ00-013 (Spanish National Institute of Agricultural Investigation, INIA) and BABE (EVK-2000-00628, European 5th Framework). 


\section{REFERENCES}

[1] Cavalli-Sforza L.L., Edwards A.W.F., Phylogenetic analysis models and estimation procedures, Evolution 3 (1967) 550-557.

[2] Colom G., El medio y la vida en las Baleares, Gráfica Miramar, Palma de Mallorca, 1964.

[3] Cornuet J.-M., The MDH polymorphism in some West Mediterranean honeybee populations, in: Breed M.D., Michener C.D., Evans H.E. (Eds.), Proceedings of the IX Congress IUSSI, Westview Press, Boulder, CO, 1982, pp. 415-416.

[4] Cornuet J.-M., Fresnaye J., Étude biométrique de colonies d'abeilles d'Espagne et du Portugal, Apidologie 20 (1989) 93-101.

[5] De la Rúa P., Galián J., Serrano J., Variabilidad mitocondrial en poblaciones de abejas de la miel del Sureste Peninsular, Invest. Agr. Prod. Sanid. Anim. 14 (1999) 24-30.

[6] De la Rúa P., Galián J., Serrano J., Moritz R F.A., Genetic structure and distinctness of Apis mellifera L. populations from the Canary Islands, Mol. Ecol. 10 (2001) 1733-1742.

[7] De la Rúa P., Galián J., Serrano J., Moritz R.F.A., Molecular characterization and population structure of the honeybees from the Balearic Islands, Apidologie 32 (2001) 417-427.

[8] De la Rúa P., Galián J., Serrano J., Biodiversity of Apis mellifera populations from Tenerife (Canary Islands) and hybridisation with East European races, Biodiv. Conserv. 11 (2002) 59-67.

[9] De la Rúa P., Galián J., Serrano J., Moritz R.F.A., Microsatellite analysis of non-migratory colonies of Apis mellifera iberica from south-eastern Spain, J. Zool. Syst. Evol. Res. 40 (2002) 164-168.

[10] Estoup A., Solignac M., Cornuet J.-M., Precise assessment of the number of patrilines and of genetic relatedness in honeybee colonies, Proc. R. Soc. London B 258 (1994) 1-7.

[11] Estoup A., Garnery L., Solignac M., Cornuet J.-M., Microsatellite variation in honeybee (Apis mellifera L.) populations: hierarchical genetic structure and test of the infinite allele and stepwise mutation models, Genetics 140 (1995) 679-695.

[12] Estoup A., Taillez C., Cornuet J.-M., Solignac M., Size homoplasy and mutational processes of interrumped microsatellites in Apidae species, Apis mellifera and Bombus terrestris, Mol. Biol. Evol. 12 (1995) 1074-1084.

[13] Felsenstein J., PHYLIP, phylogeny inference package, Version 3.5., University of Washington, Seattle, 1993.

[14] Franck P., Garnery L., Solignac M., Cornuet J.-M., The origin of west European subspecies of honeybees (Apis mellifera): new insights from microsatellite and mitochondrial data, Evolution 52 (1998) 1119-1134.

[15] Franck P., Garnery L., Celebrano G., Solignac M., Cornuet J.-M., Hybrid origin of honeybees from Italy (Apis mellifera ligustica) and Sicily (A. m. sicula), Mol. Ecol. 9 (2000) 907-921.

[16] Franck P., Garnery L., Solignac M., Cornuet J.-M., Molecular confirmation of a Middle East lineage in Apis mellifera, Apidologie 31 (2000) 167-180.

[17] Franck P., Garnery L., Loiseau A., Oldroyd B.P., Hepburn H.R., Solignac M., Cornuet J.-M., Genetic diversity of the honeybee in Africa: microsatellite and mitochondrial data, Heredity 86 (2001) 420-430. 
[18] Garnery L., Cornuet J.-M., Solignac M., Evolutionary history of the honey bee Apis mellifera inferred from mitochondrial DNA analysis, Mol. Ecol. 1 (1992) $145-154$.

[19] Garnery L., Solignac M., Celebrano G., Cornuet J.-M., A simple test using restricted PCR-amplified mitochondrial DNA to study the genetic structure of Apis mellifera L., Experientia 49 (1993) 1016-1021.

[20] Garnery L., Mosshine E.H., Cornuet J.-M., Mitochondrial DNA variation in Moroccan and Spanish honey bee populations, Mol. Ecol. 4 (1995) 465-471.

[21] Garnery L., Franck P., Baudry E., Vautrin D., Cornuet J.-M., Solignac M., Genetic biodiversity of the west European honeybee (Apis mellifera mellifera and A. $\mathrm{m}$. iberica). I. Mitochondrial DNA, Genet. Sel. Evol. 30 (1998) 31-47.

[22] Garnery L., Franck P., Baudry E., Vautrin D., Cornuet J.-M., Solignac M., Genetic biodiversity of the west European honeybee (Apis mellifera mellifera and A. $\mathrm{m}$. iberica). II. Microsatellite DNA, Genet. Sel. Evol. 30 (1998) 49-74.

[23] Goudet J., FSTAT (version 1.2): A Computer Program to Calculate F-Statistics, J. Hered. 86 (1995) 485-486.

[24] Hedges S.B., The number of replications needed for accurate estimation of the bootstrap P value in phylogenetic studies, Mol. Biol. Evol. 9 (1992) 366-369.

[25] Hepburn H.R., Radloff S.E., Morphometric and pheromonal analyses of Apis mellifera L. along a transect from the Sahara to the Pyrenees, Apidologie 27 (1996) 35-45.

[26] Nei M., Analysis of gene diversity in subdivided populations, Proc. Natl. Acad. Sci. USA 70 (1973) 3321-3323.

[27] Orantes-Bermejo F.J., García-Fernández P., Morphological variability of Apis mellifera iberica in different apiaries of southern Spain, J. Apic. Res. 34 (1995) 23-30.

[28] Palmer M., Pons G.X., Cambefort Y., Alcover J.A., Historical processes and environmental factors as determinants of inter-islands differences in endemic faunas: The case of the Balearic islands, J. Biogeogr. 26 (1999) 813-824.

[29] Radloff S.E., Hepburn H.R., Hepburn C., De la Rúa P., Morphometric affinities and population structure of honeybees of the Balearic Islands in the Mediterranean Sea, J. Apic. Res. 40 (2001) 97-103.

[30] Raymond M., Rousset F., GENEPOP (version 1.2): population genetics software for exact test and ecumenism, J. Hered. 86 (1995) 248-250.

[31] Rice W.R., Analyzing tables of statistical tests, Evolution 43 (1989) 223-225.

[32] Ruttner F., Biogeography and Taxonomy of Honeybees, Springer Verlag, Berlin, 1988.

[33] Saitou N., Nei M., The neighbour joining method a new method for reconstructing phylogenetic trees, Mol. Biol. Evol. 4 (1987) 406-425.

[34] Sheppard W.S., Rinderer T.E., Meixner M.D., Yoo H.R., Stelzer J.A., Schiff N.M., Kamel S.M., Krell R., HinfI variation in mitochondrial DNA of old world honey bee subspecies, J. Hered. 87 (1996) 35-40.

[35] Sheppard W.S., Arias M.C., Grech A., Meixner M.D., Apis mellifera ruttneri, a new honey bee subspecies from Malta, Apidologie 28 (1997) 287-293.

[36] Sinacori A., Rinderer T.E., Lancaster V., Sheppard W.S., A morphological and mitochondrial assessment of Apis mellifera from Palermo, Italy, Apidologie 29 (1998) 481-490. 
[37] Smith D.R., Palopoli M.F., Taylor B.R., Garnery L., Cornuet J.-M., Solignac M., Brown M., Geographical overlap of two mitochondrial genomes in Spanish honeybees (Apis mellifera iberica), J. Hered. 82 (1991) 96-100.

[38] Smith D.R., Glenn T.C., Allozyme polymorphism in Spanish honeybees (Apis mellifera iberica), J. Hered. 86 (1995) 12-16.

[39] Strassmann J., The rarity of multiple mating by females in the social Hymenoptera, Ins. Soc. 48 (2001) 01-13.

[40] Walsh P.S., Metzqer D.A., Higuchi R., Chelex 100 as a medium for simple extraction of DNA for PCR-based typing from forensic material, Biotechniques 10 (1991) 506-512.

To access this journal online: www.edpsciences.org 